\title{
Superparamagnetic Iron Oxide Nanoparticle- Aptamer Bioconjugates for Combined Prostate Cancer Imaging and Therapy
}

\section{Citation}

Wang, Andrew ZZ., Vaishali Bagalkot, Christophoros $\mathbb{C}$. Vasilliou, Frank Gu, Frank Alexis, Liangfang Zhang, Mariam Shaikh, et al. 2008. "Superparamagnetic Iron Oxide NanoparticleAptamer Bioconjugates for Combined Prostate Cancer Imaging and Therapy." ChemMedChem 3 (9) (September 15): 1311-1315. doi:10.1002/cmdc.200800091.

\section{Published Version}

doi:10.1002/cmdc.200800091

\section{Permanent link}

http://nrs.harvard.edu/urn-3:HUL.InstRepos:29005175

\section{Terms of Use}

This article was downloaded from Harvard University's DASH repository, and is made available under the terms and conditions applicable to Other Posted Material, as set forth at http:// nrs.harvard.edu/urn-3:HUL.InstRepos:dash.current.terms-of-use\#LAA

\section{Share Your Story}

The Harvard community has made this article openly available.

Please share how this access benefits you. Submit a story.

\section{Accessibility}




\section{Superparamagnetic Iron Oxide Nanoparticle-Aptamer Bioconjugates for Combined Prostate Cancer Imaging and Therapy}

Dr. Andrew Z. Wang ${ }^{[a, d]}$, Vaishali Bagalkot ${ }^{[b]}$, Christophoros C. Vasilliou ${ }^{[c]}$, Dr. Frank Gu ${ }^{[d]}$, Dr. Frank Alexis ${ }^{[a, d]}$, Dr. Liangfang Zhang ${ }^{[d]}$, Mariam Shaikh ${ }^{[d]}$, Kai Yuet ${ }^{[d]}$, Prof. Michael J. Cimaa $^{[e]}$, Prof. Robert Langer ${ }^{[d]}$, Prof. Philip W. Kantoff ${ }^{[f]}$, Prof. Neil H. Bander ${ }^{[g]}$, Prof. Sangyong Jon ${ }^{[b]}$, and Prof. Omid C. Farokhzad ${ }^{[a]}$

[a]Laboratory of Nanomedicine and Biomaterials, Department of Anesthesia Brighamand Women's Hospital and Harvard Medical School 75 FrancisStreet, Boston, MA 02115 (USA) Fax: (+ 1) 617-730-2801 ofarokhzad@parrtners.org

${ }^{[b]}$ Research Center for Biomolecular Nanotechnology Department of Life Science Gwangju Institute of Science and Technology 1 Oryong-dong, Buk-gu, Gwangju 500712 (South Korea) Fax: (+ 82) 62-970-2504 syjon@gist.ac.kr

[c]Department of Electrical Engineering and Computer Science Massachusetts Institute of Technology 77 Massachusetts Ave., Cambridge, MA 02139 (USA)

${ }^{[d]}$ Department of Chemical Engineering Division of Health Science and Technology Massachusetts Institute of Technology 77 Massachusetts Ave., Cambridge, MA 02139 (USA)

[e]Department of Material Science and Engineering, David H. Koch Institute for Integrative Cancer Research Massachusetts Institute of Technology 77 Massachusetts Ave., Cambridge, MA 02139 (USA)

[f]Lank Center for Genitourinary Oncology Dana Farber Cancer Institute and Harvard Medical School 44 Binney Street, Boston, MA 02115 (USA)

[g]Department of Urology, Weill Medical College of Cornell University New York, NY 10021 (USA)

\section{Keywords}

doxorubicin; nanoparticles; superparamagnetic; TCL-SPION

Over the past two decades, molecular targeted diagnostic and therapeutic agents have dramatically improved cancer diagnosis and treatment. ${ }^{[1-8]}$ Targeting allows the preferential delivery of therapeutic, diagnostic, or imaging agents to the intended site. Advances in nanotechnology have enabled the development of a variety of targeted nanoparticle platforms for diagnostic and therapeutic applications. ${ }^{[9-11]}$ Preclinical data have shown that targeted nanoparticle systems accumulate preferentially in the target tissue, demonstrating the vast potential of targeted nanoparticles. ${ }^{[12-14]}$ In addition, the development of multifunctional nanoparticle platforms, with both diagnostic and therapeutic capabilities, may allow in vivo monitoring of both biodistribution of the nanocarriers and tumor response to therapy. ${ }^{[11,15-17]}$ Therefore, research efforts have been focused on the further development of multifunctional molecular agents for the diagnosis and treatment of cancer.

(C) 2008 Wiley-VCH Verlag GmbH \& Co. KGaA, Weinheim

$\left[+{ }^{[+}\right.$These authors contributed equally. 
One of the most promising diagnostic agents is superparamagnetic iron oxide nanoparticles (SPION) ${ }^{[18]}$ SPION have several important advantages over traditional gadolinium-based magnetic resonance (MR) contrast agents: lower toxicity, stronger enhancement of proton relaxation, and lower detection limit. ${ }^{[19,20]}$ Ferumoxtran-10 (Combidex), a dextran-coated SPION with a mean diameter of $\sim 30 \mathrm{~nm}$, is currently in phase III clinical trials for prostate cancer (PCa) imaging. ${ }^{[21]}$ Combidex has a $90.5 \%$ sensitivity and $97.8 \%$ specificity for detecting PCa lymph node disease by passively accumulating in metastatic nodes. ${ }^{[22]}$ The major shortcoming of Combidex is its inability to detect PCa disease outside of the lymph nodes.

Herein, we report the development of a novel, multifunctional, thermally cross-linked SPION (TCL-SPION) that can both detect PCa cells, and deliver targeted chemotherapeutic agents directly to the PCa cells. We previously reported the use of the A10 RNA aptamer (Apt), which binds the extracellular domain of the prostate-specific membrane antigen (PSMA), to engineer targeted nanoparticles for PCa therapy and imaging. ${ }^{[12,13,23]}$ PSMA is a well-established marker for PCa cells, with relatively low levels of expression in normal prostate, kidney, brain, and small intestine tissue. ${ }^{[24]}$ The percentage of PCa cells that express PSMA approaches $100 \%$ with highest expression in androgen-independent $\mathrm{PCa}$ cells. ${ }^{[25,26]}$ Additionally, we have shown that the A10 aptamer can be used to deliver doxorubicin (Dox), a chemotherapeutic agent, by intercalation of Dox into the CG sequence in the aptamer. ${ }^{[23,27,28]}$ By combining the above concepts, we have formulated SPION-Apt bioconjugates for combined PCa imaging and therapy. The components of the nanoparticle include: a) N-terminated A10 aptamer, a 57-bp nuclease-stabilized 2'-fluoropyrimidine RNA molecule modified with $\mathrm{C}_{18}$-amine at the $3^{\prime}$ end, for targeting PSMA-expressing PCa cells, and acting as a carrier for Dox; b) TCL-SPION coated with a carboxylic acid-PEG-derived, anti-biofouling polymer, ${ }^{[29]}$ which acts as both a MR contrast agent and as a carrier for Dox; and c) Dox, a chemotherapeutic agent that is intercalated in the aptamer and complexed with the TCL-SPION through charge interactions. The hydroxy and carbonyl groups on the surface of the TCL-SPION make them apt for the formulation of targeted nanoparticle platforms. The PEGylated surface prevents protein and cell adsorption, while the carboxyl groups allow conjugation of targeting moieties, like the A10 aptamer. TCL-SPIONs are also well suited for therapeutic delivery because of their low toxicity profiles. ${ }^{[30-32]}$

Conjugation of the TCL-SPION with an A10 aptamer, using standard coupling chemistry, gave the TCL-SPION-Apt bioconjugate formulation (Figure $1 \mathrm{a}$ ); conjugation led to an increase in both size $(60.8 \pm 1.9$ to $66.4 \pm 1.5 \mathrm{~nm})$, and $\zeta$-potential $(-36.0 \pm 1.8$ to $-42.7 \pm 3.8$ $\mathrm{mV}$ ) of the nanoparticles. The conjugation of the A10 aptamer to TCL-SPION was confirmed using agarose gel electrophoresis (Figure $1 \mathrm{~b}$ ); the free A10 aptamers matched the 60-bp band in the 100-bp ladder, and the TCL-SPION-Apt bioconjugate lane showed a band at a much higher molecular weight, confirming the conjugation of Apt to TCL-SPION.

Differential uptake of the TCL-SPION-Apt bioconjugate by PSMA-expressing PCa cells (LNCaP), compared with non-PSMA-expressing PCa cells (PC3), was then confirmed in whole-cell assays by comparison with the uptake of TCL-SPION . Monitoring the uptake at regular time intervals $(1,3,6,12,18$ and $24 \mathrm{~h})$ and using the Prussian blue reaction to visualize uptake, intracellular TCL-SPION-Apt bioconjugate uptake in LNCaP cells was detected as early as $3 \mathrm{~h}$ after dosing and progressively increases in a time-dependent manner. In contrast, TCL-SPION-Apt bioconjugates incubated with PC3 cells, and TCL-SPION incubated with LNCaP and PC3 cells, did not show intracellular uptake of the nanoparticles (Figure 2). These results confirm that TCL-SPION-Apt bioconjugates can differentially target PSMA-expressing PCa cells. 
The potential of the TCL-SPION-Apt bioconjugate as a targeted MR contrast agent was investigated by NMR studies. The longitudinal relaxation time $\left(T_{1}\right)$, and the transverse relaxation time $\left(T_{2}\right)$ of the TCL-SPION-Apt bioconjugate and non-targeted TCL-SPION was measured using a single-sided NMR probe, after incubation with $\mathrm{LNCaP}$ and $\mathrm{PC} 3$ cells $(6 \mathrm{~h})$, and resuspension in Matrigel to simulate prostate tumors. Only a small change in $T_{1}$ and $T_{2}$ was observed for the non-targeted TCL-SPION in LNCaP cells $\left(T_{1}: 1939 \pm 116\right.$ to $1521 \pm 201 \mathrm{~ms} ; T_{2}: 104.2 \pm 1.4$ to $89.8 \pm 1.1 \mathrm{~ms}$ ), however, the TCL-SPION-Apt bioconjugate led to a dramatic decrease in $T_{1}$ and $T_{2}\left(T_{1}: 1939 \pm 116\right.$ to $263 \pm 23 \mathrm{~ms} ; T_{2}: 104.2 \pm 1.4$ to $26.6 \pm 0.4 \mathrm{~ms})$. As expected, TCL-SPION-Apt bioconjugates did not lead to significant reduction of $T_{1}$ and $T_{2}$ relaxation times in PC3 cells (Figure 3). These data suggest that TCL-SPION-Apt bioconjugates can detect PSMA-expressing PCa cells with high sensitivity.

After demonstrating the TCL-SPION-Apt bioconjugate's potential as a targeted MRI contrast agent, its potential as a therapeutic carrier was investigated. Firstly, the amount of Dox that can bind to the TCL-SPION-Apt bioconjugate through intercalation into the aptamer, and adsorption into the negatively charged polymer surface of the nanoparticle was determined. We had previously shown that the conjugation of Dox results in the quenching of its fluorescence. ${ }^{[27,33]}$ Using a spectrofluorophotometer, we titrated increasing concentrations of TCL-SPION and TCL-SPION-Apt bioconjugate against a fixed amount of Dox. As seen in Figure 4, the amount of TCL-SPION and TCL-SPION-Apt bioconjugates needed to quench $12 \mu \mathrm{g}$ of Dox were 0.52 and $0.44 \mathrm{mg}$, respectively, giving loading

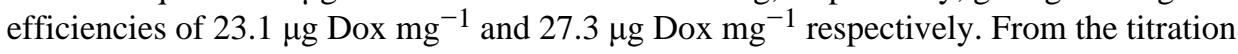
data, approximately $15 \%$ of Dox was intercalated in the aptamer and approximately $85 \%$ was bound to the polymer by electrostatic interactions.

The Dox-loaded TCL-SPION-Apt bioconjugates were evaluated for antiproliferation activity against both the $\mathrm{LNCaP}$ and $\mathrm{PC} 3$ cell lines (Figure 5). While free Dox was equipotent against both LNCaP and PC3 cell lines, the Dox-loaded TCL-SPION-Apt bioconjugate was significantly more potent against the PMSA-expressing LNCaP cells relative to the non-targeted PC3 cells (cell viability: LNCaP $47.3 \pm 1.4 \%$ vs. PC3 $69.3 \pm 1.7$ $\%)$. The data also showed that the cytotoxicity of Dox-loaded TCL-SPION-Apt bioconjugates was nearly as potent as free Dox. The observed cytotoxicity of Dox-loaded TCL-SPION-Apt bioconjugates to PC 3 cells $(69.3 \pm 1.7 \%$ compared with $95.7 \pm 1.9 \%$ of control) was likely due to uptake of Dox released after the dissociation of Dox from TCLSPION-Apt bioconjugates.

In summary, a novel multifunctional TCL-SPION-Apt bioconjugate was synthesized, and shown to detect and treat PCa cells in vitro. However, the potential of TCL-SPION-Apt bioconjugates as targeted MR contrast agents for imaging of PCa needs to be further validated using in vivo models. TCL-SPION-Apt bioconjugates can be used as therapeutic carriers for the delivery of Dox, leading to selective delivery to PSMA-expressing cells without significant loss in cytotoxicity. The lack of sensitive and specific imaging agents, and effective therapeutic approaches for disseminated $\mathrm{PCa}$, makes multifunctional nanoparticle technologies, such as TCL-SPION-Apt bioconjugates, a potential approach for both the detection and the treatment of disseminated PCa. ${ }^{[34-37]}$ More broadly, the unique advantages of such multifunctional nanoparticles with diagnostic and therapeutic capabilities include: 1) targeted delivery of therapeutics to disease cells only, 2) observation of therapeutic delivery, and 3) detection of therapeutic response. Through the use of other disease-specific aptamers or other targeting molecules, as well as other strategies to conjugate therapeutic agents, similar multifunctional nanoparticles can be developed for applications in medicine. 


\section{Experimental Section}

\section{TCL-SPION-Apt bioconjugate}

A solution of carboxy-TCL-SPION $(50 \mu \mathrm{L}, 1.5 \mathrm{mg})^{[29]}$ was treated with $N$-(3dimethylaminopropyl)- $N$ '-ethylcarbodiimide (EDC) $(25 \mu \mathrm{L}, 400 \mathrm{mM})$ and $N$ hydroxysuccinimide (NHS) $(25 \mu \mathrm{L}, 100 \mathrm{~m} \mathrm{M})$ and gently shaken for $15 \mathrm{~min}$. N-terminated Aptamer (RNA-TEC, Belgium, $1 \mathrm{mg}$ in $100 \mu \mathrm{L}$ ) was then added, and the solution gently shaken for a further $4 \mathrm{~h}$. Unreacted aptamer was removed using centrifugal filtration, five times (3,000 rpm, Nanosep centrifugal devices, $300 \mathrm{~K}$, Pall Corp). Gel electrophoresis was carried out on $1.8 \%$ agarose gels; $0.05 \mathrm{mg}$ of TCL-SPION-Apt bioconjugate and TCLSPION were loaded. Tris-acetate-EDTA (TAE) buffer was used for the electrophoresis experiments. (Figure $1 \mathrm{~b}$ and Supporting Information, figure 1)

\section{Iron (Prussian blue) stain}

LNCaP and PC 3 cell lines were grown in eight-well microscope chamber slides in RPMI-1640 and Ham's F-12 K medium respectively; both were treated with aqueous penicillin $\mathrm{G}\left(100 \mathrm{U} \mathrm{mL}^{-1}\right)$, streptomycin $\left(100 \mu \mathrm{gmL}^{-1}\right)$, and $10 \%$ fetal bovine serum (FBS). Cells were grown to $70 \%$ confluency ( 40000 cells $\mathrm{cm}^{-2}$ ). Prior to dosing, cells were washed with PBS buffer and incubated with fresh media for $30 \mathrm{~min}$. Cells were dosed with TCL-SPION-Apt bioconjugate or TCL-SPION $\left(0.1 \mathrm{mgmL}^{-1}\right)(n=4)$ and incubated for 3-24 $\mathrm{h}$ at $37^{\circ} \mathrm{C}$, then washed two times with PBS and fixed with $4 \%$ formaldehyde. The cells were stained using the HT20 Iron Stain Kit (Sigma-Aldrich), and imaged with light microscopy.

\section{Quantification of Dox loading}

The amount of Dox loading onto TCL-SPION-Apt bioconjugate was calculated by fluorescence titration method. Before titration, the concentrations of TCL-SPION and TCLSPION-Apt bioconjugate were determined from a standard curve of TCL-SPION at $310 \mathrm{~nm}$ (data not included). ${ }^{[22]}$ Increasing concentrations of TCL-SPION $\left(7.46 \mathrm{mgmL}^{-1} ; 5,15,30\right.$, $36,52,100,150,260,360$ and $520 \mu \mathrm{g})$ or TCL-SPION-Apt bioconjugate $\left(6.3 \mathrm{mgmL}^{-1} ; 4\right.$, $13,22,31,44,88,133,220,311$ and $440 \mu \mathrm{g})$ were added stepwise to a fixed concentration of Dox (12 $\mu \mathrm{g}$ in $0.45 \mathrm{~mL})$. After each addition, the solution was mixed well and incubated at room temperature for $10 \mathrm{~min}$. The fluorescence spectra were recorded by exciting the solution at $480 \mathrm{~nm}$ and recording the emission at $500-720 \mathrm{~nm}$ ( $3 \mathrm{~mm}$ slit) on a Shimadzu RF-PC100 spectrofluorophotometer. The maximum loading amount was defined as the concentration of nanoparticle required to give a $95 \%$ reduction in fluorescence emission compared with the spectra of an untreated solution of Dox.

\section{$T_{1}$ and $T_{2}$ relaxation time measurements}

LNCaP and PC3 cell lines were grown in six-well plates to $\sim 100 \%$ confluency. Prior to dosing, cells were washed with PBS buffer and incubated with fresh media for $30 \mathrm{~min}$. Cells were dosed with TCL-SPION-Apt bioconjugate or TCL-SPION $\left(0.1 \mathrm{mgmL}^{-1}\right)(n=4)$ and incubated for $6 \mathrm{~h}$ at $37^{\circ} \mathrm{C}$, then washed two times with PBS, detached with trypsin, and fixed with $4 \%$ formaldehyde. Approximately one million cells of each sample were resuspended in $100 \mu \mathrm{L}$ of Matrigel and placed inside a standard eight-well strip (Greiner Bio-One). Measurements were performed on a single-sided NMR probe at $25^{\circ} \mathrm{C}$ at an operating frequency of $18.55 \mathrm{MHz}$ (Profile NMR MOUSE, ACT Center for Technology, Aachen, Germany). A Minispec spectrometer (Bruker Optics, The Woodlands, TX, USA) was used for pulse sequence generation and data acquisition. A computer-controlled motion stage (Newport Corporation, Irvine, CA) positioned each well over the sensitive volume, and custom software, written in LabView (National Instruments, Austin, TX), coordinated 
the measurements. The acquisition time was approximately $30 \mathrm{~s}$ per sample. The longitudinal relaxation time $T_{1}$ was measured using a saturation recovery sequence. The signal intensity was measured with a short Carr Purcell Meiboom Gill (CPMG) echo sequence following a saturation pulse sequence, and a recovery time $\Delta$. The echo time, TE, was $0.035 \mathrm{~ms}$ and 114 echoes were acquired for each time point. Seven time points were acquired per sample. The transverse relaxation time, $T_{2}$, was measured using a CPMG pulse sequence lasting $200 \mathrm{~ms}$ with an echo time of $0.035 \mathrm{~ms}$. The data were averaged over 16 scans and the recovery time (TR) was $1.25 \mathrm{~s}$ for Sample 2 and $2.5 \mathrm{~s}$ for the others. The NMR sensor's static field gradient contributes to lower $T_{2}$ values and limits the maximum measurable $T_{2}$. The measured $T_{2}$ values were all within the operating range of the instrument. The data were fit using a custom script running on MATLAB (The Mathworks, Natick, MA).

$$
I=I_{0}\left(1-e^{-\frac{\Delta}{T_{1}}}\right) \quad I=I_{0} e^{-\frac{t}{T_{2}}}
$$

\section{MTT cell proliferation assay}

LNCaP and PC3 cell lines were grown in 48-well plates in RPMI-1640 and Ham's F-12 K medium, respectively; both were treated with aqueous penicillin $\mathrm{G}\left(100 \mathrm{U} \mathrm{mL}^{-1}\right)$, streptomycin $\left(100 \mu \mathrm{gmL}^{-1}\right)$, and $10 \% \mathrm{FBS}$, at concentrations so as to allow $70 \%$ confluence in $24 \mathrm{~h}\left(\sim 40000\right.$ cells cm $\left.\mathrm{cm}^{-2}\right)$. Prior to dosing, cells were washed with PBS buffer and incubated with fresh media for $30 \mathrm{~min}$.

Cells were dosed with TCL-SPION-Apt(Dox) bioconjugates $\left(0.1 \mathrm{mgmL}^{-1}, 5 \mu_{\mathrm{M}}\right.$ Dox), TCL-SPION $\left(0.1 \mathrm{mgmL}^{-1}\right)$, or free Dox $\left(5 \mu_{\mathrm{M}}\right)$ and incubated for $3 \mathrm{~h}$ at $37^{\circ} \mathrm{C}$, then washed two times with PBS, and further incubated in fresh growth media for a total of $48 \mathrm{~h}$. Cell viability was assessed colorimetrically with the MTT reagent (ATCC) following the standard protocol provided by the manufacturer. The absorbance was read with a microplate reader at $570 \mathrm{~nm}$.

\section{Supplementary Material}

Refer to Web version on PubMed Central for supplementary material.

\section{Acknowledgments}

We thank Drs. Ralph Weissleder and Lee Josephson for helpful discussions throughout this study. This work was supported by the National Institutes of Health(USA) grants CA119349 (R.L., O.C.F.), EB003647 (O.C.F.), David H. Koch-Prostate Cancer Foundation Award in Nanotherapeutics (R.L., P.W.K, N.H.B, O.C.F.), and by a grant from the National R\&D Program for Cancer Control, Ministry of Health and Welfare(Republic of Korea) 0720210 (S.J.).

\section{References}

[1]. Conti PS, Lilien DL, Hawley K, Keppler J, Grafton ST, Bading JR. Nucl. Med. Biol. 1996; 23:717. [PubMed: 8940714]

[2]. Romond EH, Perez EA, Bryant J, Suman VJ, Geyer CE Jr. Davidson NE, Tan-Chiu E, Martino S, Paik S, Kaufman PA, Swain SM, Pisansky TM, Fehrenbacher L, Kutteh LA, Vogel VG, Visscher DW, Yothers G, Jenkins RB, Brown AM, Dakhil SR, Mamounas EP, Lingle WL, Klein PM, Ingle JN, Wolmark N. N. Engl. J. Med. 2005; 353:1673. [PubMed: 16236738]

[3]. Piccart-Gebhart MJ, Procter M, Leyland-Jones B, Goldhirsch A, Untch M, Smith I, Gianni L, Baselga J, Bell R, Jackisch C, Cameron D, Dowsett M, Barrios CH, Steger G, Huang CS, Andersson M, Inbar M, Lichinitser M, Lang I, Nitz U, Iwata H, Thomssen C, Lohrisch C, Suter 
TM, Ruschoff J, Suto T, Greatorex V, Ward C, Straehle C, McFadden E, Dolci MS, Gelber RD. N. Engl. J. Med. 2005; 353:1659. [PubMed: 16236737]

[4]. Coiffier B, Lepage E, Briere J, Herbrecht R, Tilly H, Bouabdallah R, Morel P, Van Den Neste E, Salles G, Gaulard P, Reyes F, Lederlin P, Gisselbrecht C. N. Engl. J. Med. 2002; 346:235. [PubMed: 11807147]

[5]. Czuczman MS, Weaver R, Alkuzweny B, Berlfein J, Grillo-Lopez AJ. J. Clin. Oncol. 2004; 22:4711. [PubMed: 15483015]

[6]. Hiddemann W, Kneba M, Dreyling M, Schmitz N, Lengfelder E, Schmits R, Reiser M, Metzner B, Harder H, Hegewisch-Becker S, Fischer T, Kropff M, Reis HE, Freund M, Wormann B, Fuchs R, Planker M, Schimke J, Eimermacher H, Trumper L, Aldaoud A, Parwaresch R, Unterhalt M. Blood. 2005; 106:3725. [PubMed: 16123223]

[7]. Zhang H, Berezov A, Wang Q, Zhang G, Drebin J, Murali R, Greene MI. J. Clin. Invest. 2007; 117:2051. [PubMed: 17671639]

[8]. Hudis CA. N. Engl. J. Med. 2007; 357:39. [PubMed: 17611206]

[9]. Kumar S, Richards-Kortum R. Nanomedicine. 2006; 1:23. [PubMed: 17716206]

[10]. Pridgen EM, Langer R, Farokhzad OC. Nanomedicine. 2007; 2:669. [PubMed: 17976029]

[11]. McCarthy JR, Kelly KA, Sun EY, Weissleder R. Nanomedicine. 2007; 2:153. [PubMed: 17716118]

[12]. Farokhzad OC, Cheng J, Teply BA, Sherifi I, Jon S, Kantoff PW, Richie JP, Langer R. Proc. Natl. Acad. Sci. USA. 2006; 103:6315. [PubMed: 16606824]

[13]. Farokhzad OC, Jon S, Khademhosseini A, Tran TN, Lavan DA, Langer R. Cancer Res. 2004; 64:7668. [PubMed: 15520166]

[14]. Kim SH, Jeong JH, Chun KW, Park TG. Langmuir. 2005; 21:8852. [PubMed: 16142970]

[15]. Nasongkla N, Bey E, Ren J, Ai H, Khemtong C, Guthi JS, Chin SF, Sherry AD, Boothman DA, Gao J. Nano Lett. 2006; 6:2427. [PubMed: 17090068]

[16]. Kohler N, Sun C, Fichtenholtz A, Gunn J, Fang C, Zhang M. Small. 2006; 2:785. [PubMed: 17193123]

[17]. Rhyner MN, Smith AM, Gao X, Mao H, Yang L, Nie S. Nanomedicine. 2006; 1:209. [PubMed: 17716110]

[18]. Weissleder R. Science. 2006; 312:1168. [PubMed: 16728630]

[19]. Wang YX, Hussain SM, Krestin GP. Eur. Radiol. 2001; 11:2319. [PubMed: 11702180]

[20]. Weissleder R, Elizondo G, Wittenberg J, Rabito CA, Bengele HH, Josephson L. Radiology. 1990; 175:489. [PubMed: 2326474]

[21]. Leenders W. IDrugs. 2003; 6:987. [PubMed: 14534857]

[22]. Harisinghani MG, Weissleder R. PLoS Med. 2004; 1:e66. [PubMed: 15630471]

[23]. Bagalkot V, Zhang L, Levy-Nissenbaum E, Jon S, Kantoff PW, Langer R, Farokhzad OC. Nano Lett. 2007; 7:3065. [PubMed: 17854227]

[24]. Israeli RS, Powell CT, Corr JG, Fair WR, Heston WD. Cancer Res. 1994; 54:1807. [PubMed: 7511053]

[25]. Troyer JK, Beckett ML, Wright GL Jr. Int. J. Cancer. 1995; 62:552. [PubMed: 7665226]

[26]. Troyer JK, Beckett ML, Wright GL Jr. Prostate. 1997; 30:232. [PubMed: 9111600]

[27]. Bagalkot V, Farokhzad OC, Langer R, Jon S. Angew. Chem. Int. Ed. 2006; 45:8149.

[28]. Zhang L, Radovic-Moreno AF, Alexis F, Gu FX, Basto PA, Bagalkot V, Jon S, Langer RS, Farokhzad OC. ChemMedChem. 2007; 2:1268. [PubMed: 17600796]

[29]. Lee H, Yu MK, Park S, Moon S, Min JJ, Jeong YY, Kang HW, Jon S. J. Am. Chem. Soc. 2007; 129:12739. [PubMed: 17892287]

[30]. Bellin MF, Roy C, Kinkel K, Thoumas D, Zaim S, Vanel D, Tuchmann C, Richard F, Jacqmin D, Delcourt A, Challier E, Lebret T, Cluzel P. Radiology. 1998; 207:799. [PubMed: 9609907]

[31]. Anzai Y, Piccoli CW, Outwater EK, Stanford W, Bluemke DA, Nurenberg P, Saini S, Maravilla KR, Feldman DE, Schmiedl UP, Brunberg JA, Francis IR, Harms SE, Som PM, Tempany CM. Radiology. 2003; 228:777. [PubMed: 12954896] 
[32]. Harisinghani MG, Barentsz J, Hahn PF, Deserno WM, Tabatabaei S, van de Kaa CH, de La Rosette J, Weissleder R. N. Engl. J. Med. 2003; 348:2491. [PubMed: 12815134]

[33]. Yu MK, Jeong YY, Park J, Park S, Kim JW, Min JJ, Kim K, Jon S. Angew. Chem. Int. Ed. 2008 DOI: $10.1002 /$ anie.200800857.

[34]. Hricak H, Dooms GC, Jeffrey RB, Avallone A, Jacobs D, Benton WK, Narayan P, Tanagho EA. Radiology. 1987; 162:331. [PubMed: 3797645]

[35]. Kurhanewicz J, Vigneron DB, Males RG, Swanson MG, Yu KK, Hricak H. Radiol. Clin. North Am. 2000; 38:115. [PubMed: 10664669]

[36]. Tempany CM, Zhou X, Zerhouni EA, Rifkin MD, Quint LE, Piccoli CW, Ellis JH, McNeil BJ. Radiology. 1994; 192:47. [PubMed: 8208963]

[37]. Wolf JS Jr. Cher M, Dall'era M, Presti JC Jr. Hricak H, Carroll PR. J. Urol. 1995; 153:993. [PubMed: 7853590]

[38]. Pisanic TR II, Blackwell JD, Shubayev VI, Finones RR, Jin S. Biomaterials. 2007; 28:2572. [PubMed: 17320946] 
a)
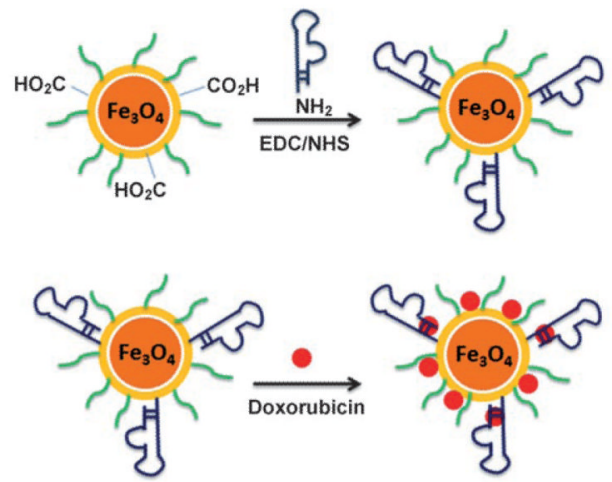

b)

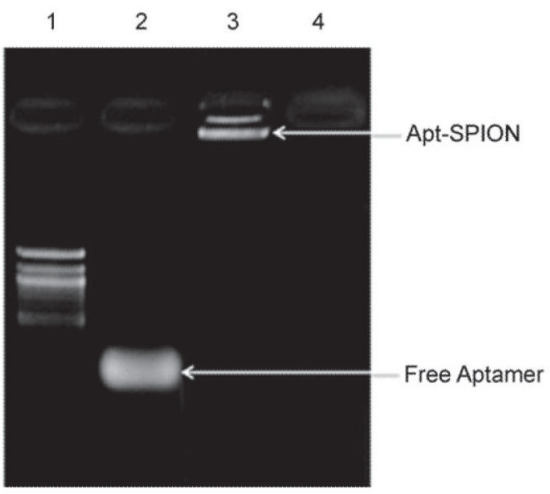

Figure 1.

a) Schematic illustration of the TCL-SPION-Apt bioconjugate system; b) confirmation of TCL-SPION-Apt bioconjugate formation by gel electrophoresis (1. 100-bp ladder; 2. A10 aptamer; 3. TCL-SPION-Apt bioconjugate; 4. TCL-SPION). 


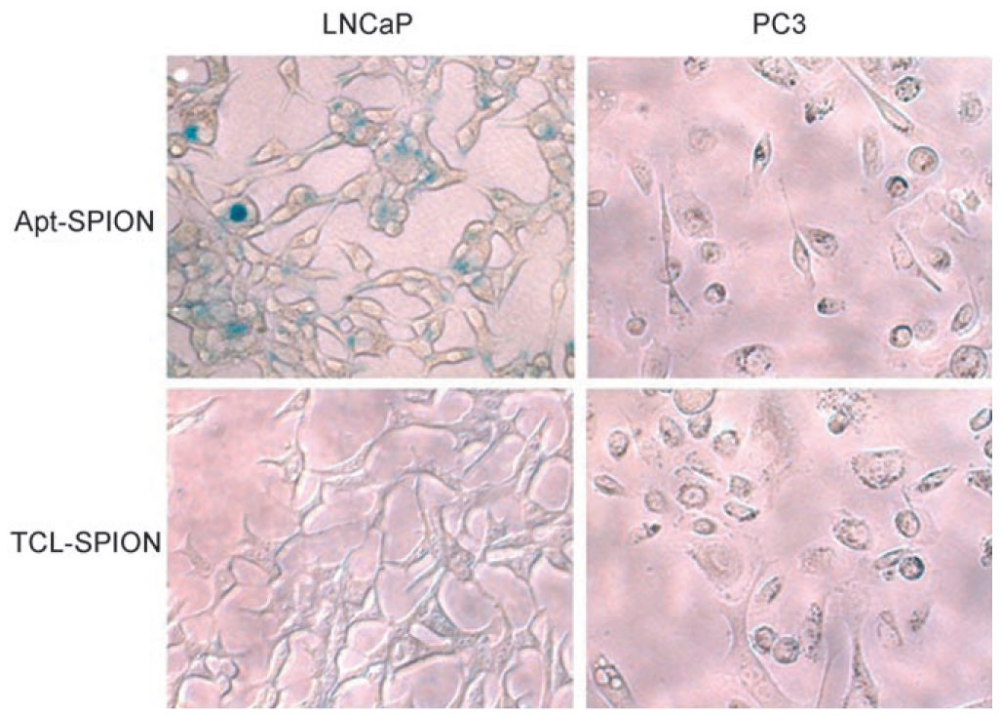

Figure 2.

Prussian blue stained LNCaP and PC3 cells after incubation with TCL-SPION-Apt bioconjugate and non-targeted TCL-SPION. 
a)

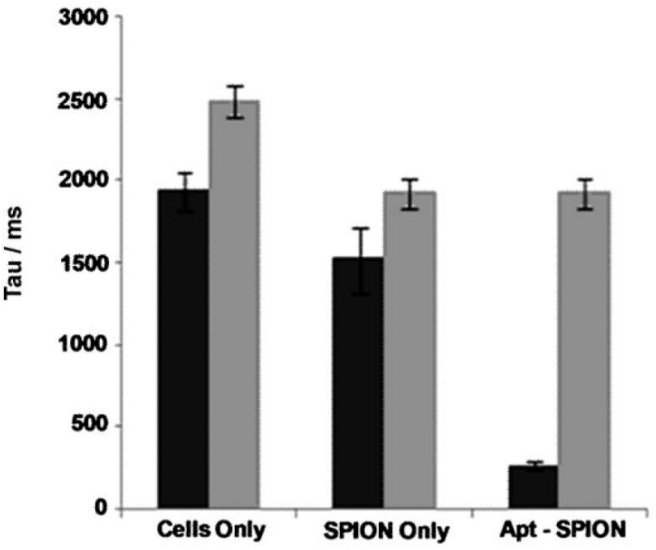

b)

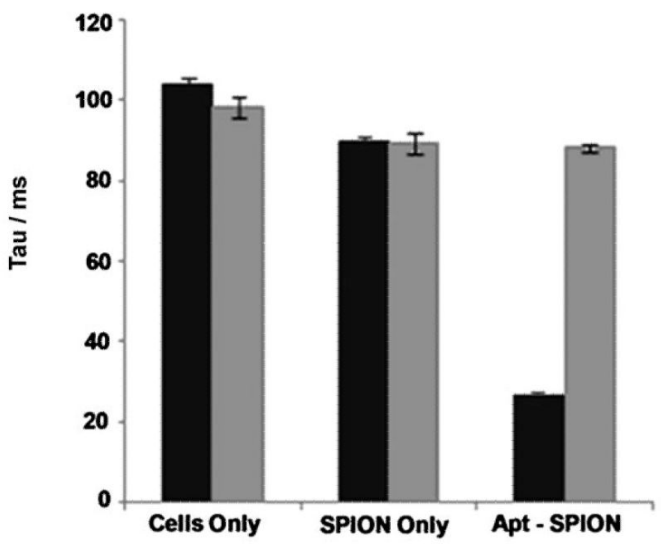

Figure 3.

a) $T_{1}$ longitudinal relaxation times of $\mathrm{LNCaP}(\mathbf{\square})$ and PC3 ( $\left.\square\right)$ cells incubated with TCLSPION and TCL-SPION-Apt bioconjugates; b) $T_{2}$ transverse relaxation times of LNCaP ( $\left.\mathbf{\square}\right)$ and PC3 (অ) cells incubated with TCL-SPION and TCL-SPION-Apt bioconjugates. 

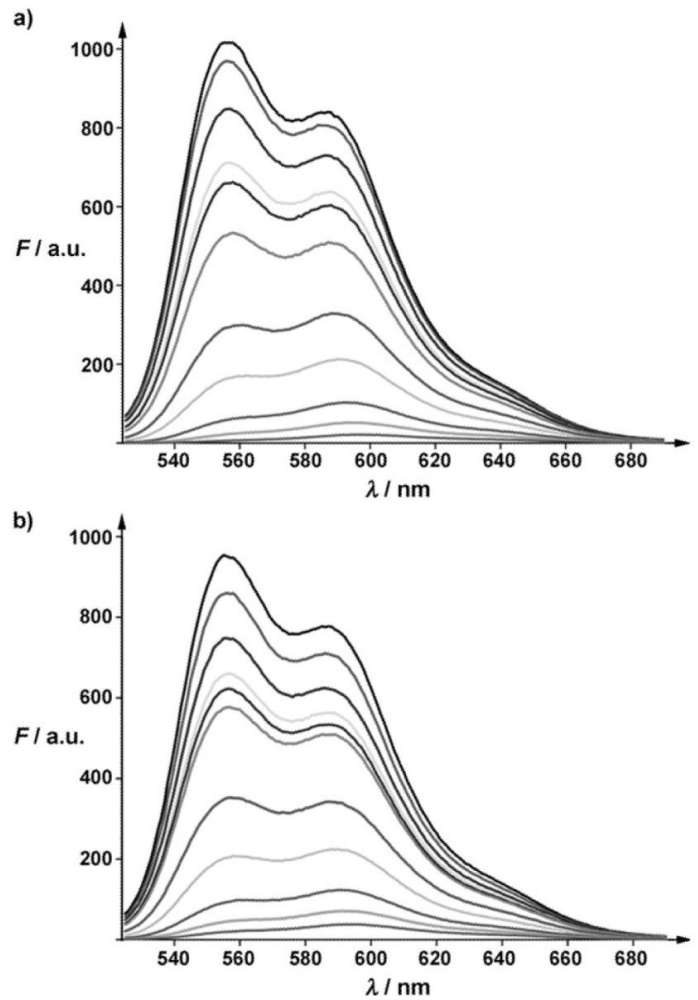

Figure 4.

Fluorescence spectra of doxorubicin solution $(12 \mu \mathrm{g}$ in $0.45 \mathrm{~mL})$ with increasing amounts of a) TCL-SPION (from top to bottom: 5, 15, 30, 36, 52, 100, 150, 260, 360, and $520 \mu \mathrm{g}$ ) and b) TCL-SPION-Apt (from top to bottom: 4, 13, 22, 31, 44, 88, 133, 220, 311, and $440 \mu \mathrm{g}$ ). 


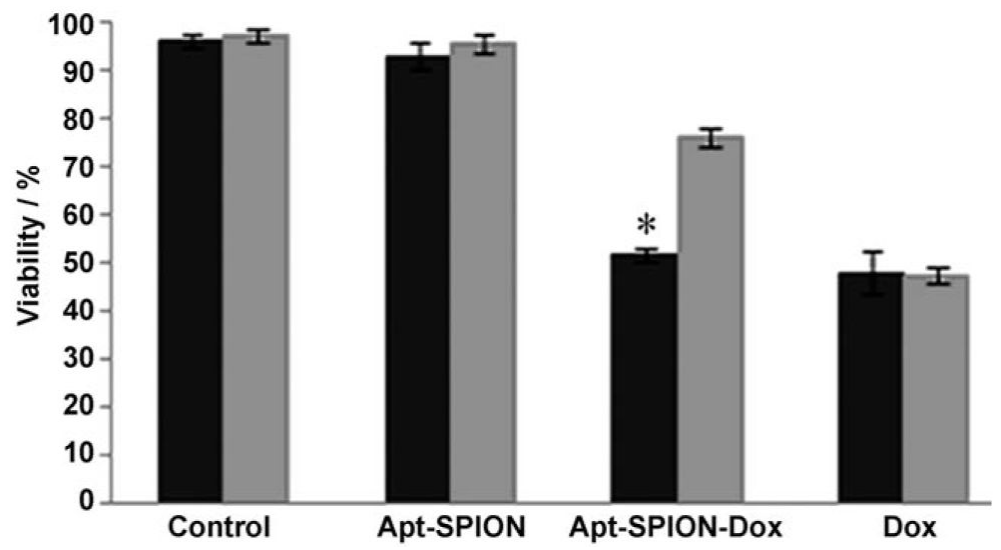

Figure 5.

MTT cell proliferation assay ( $\mathrm{LNCaP} \mathbf{m}$; $\mathrm{PC} 3 \square ;{ }^{*} p<0.005, \mathrm{n}=3$ ). 